\title{
Acute Liver Failure Induced by Thioacetamide: Selection of Optimal Dosage in Wistar and Lewis Rats
}

\author{
E. KOBLIHOVÁ ${ }^{1}$, I. MRÁZOVÁ ${ }^{2}$, Z. VERNEROVÁ $^{2,3}$, M. RYSKA ${ }^{1}$ \\ ${ }^{1}$ Department of Surgery, Second Faculty of Medicine, Charles University and Central Military \\ Hospital, Prague, Czech Republic, ${ }^{2}$ Center for Experimental Medicine, Institute for Clinical and \\ Experimental Medicine, Prague, Czech Republic, ${ }^{3}$ Department of Pathology, Third Faculty of \\ Medicine, Charles University, Prague, Czech Republic
}

Received October 29, 2013

Accepted February 14, 2014

On-line April 3, 2014

\section{Summary}

Acute liver failure (ALF) is a clinical condition with very high mortality rate. Its pathophysiological background is still poorly understood, which necessitates a search for optimal experimental ALF models with features resembling those of the human disorder. Taking into consideration reproducibility of induction of $A L F$, adequate animal size, cost of animals, the required time gap between insult and death of animals ("therapeutic window"), potential risk to investigator and other aspects, administration of thioacetamide (TAA) in rats is currently most recommended. However, the fundamental details of this ALF model have not yet been evaluated. This prompted us to investigate, first, the course of ALF as induced by intraperitoneal TAA at doses increasing from 175 to $700 \mathrm{mg} / \mathrm{kg}$ BW per day. The animals' survival rate, plasma alanine and aspartate aminotransferase activities, and bilirubin and ammonia levels were determined over the follow-up period. Second, we examined whether Wistar and Lewis rats exhibit any differences in the course of ALF induced by different TAA doses. We found that the optimal dose for ALF induction in rats is $350 \mathrm{mg.kg}{ }^{-1}$ i.p., given as a single injection. Wistar rats proved more susceptible to the development of TAA-induced ALF compared with Lewis rats. Collectively, our present findings provide a sound methodological background for experimental studies aimed at evaluation of pathophysiology and development of new approaches in the therapy of ALF.

\section{Key words}

Acute liver failure $\bullet$ Thioacetamide $\bullet$ Wistar rats $\bullet$ Lewis rats

\section{Corresponding author}

E. Koblihová, Department of Surgery, Second Faculty of
Medicine, Charles University and Central Military Hospital, Prague, U Vojenské nemocnice 1200, CZ-169 02 Prague 6, Czech Republic. Fax: +420 2 41721666. E-mail: eva.koblihova@uvn.cz

\section{Introduction}

Acute liver failure (ALF) is a condition characterized by rapid and severe deterioration of hepatocyte function in patients with originally normal liver function. ALF is accompanied by hepatic encephalopathy and mortality rate as high as $80 \%$, even if intensive care is provided (Wu et al. 2010, Lee 2012, Tritto et al. 2012, Wlodzimirow et al. 2012, Bernal and Wendon 2013). Urgent orthotopic liver transplantation has been demonstrated as the most effective therapy for ALF, however, this treatment option is limited by scarcity of donor organs. This problem is best documented by the fact that in the United States of all the patients with severe liver failure (i.e. those scored $>30$ in the Model for End-Stage Liver Disease), waiting for transplantation, about $20 \%$ die before obtaining a donor liver (Kim et al. 2006, 2010, Berg et al. 2011, Wlodzimirow et al. 2012). Therefore, other treatment approaches, such as e.g. application of bioartificial livers, have been considered to bridge the time gap to liver transplantation or regeneration (Bonavita et al. 2010, Tritto et al. 2010, Yu et al. 2012, Bañarez et al. 2013). However, the effectiveness of the new methods for treatment of ALF has not yet been convincingly demonstrated (Wlodzimirov et al. 2012, Bañarez et al. 2013) and current knowledge of the pathophysiology of ALF is still limited (Wu et al. 2010, Bernal and Wendon 2013). 
Therefore, to evaluate new therapeutical means for treatment of ALF there is an obvious need for functional studies using animal models. Numerous studies have been performed in an attempt to develop optimal models to study pathophysiology of ALF, both in large (dogs, goats and pigs) and small (rats and mice) animals. To induce liver injury needed for the development of ALF surgical techniques or hepatotoxic drugs were applied (Butterworth et al. 2009, Ryska et al. 2009, 2012, Tuñón et al. 2009, Kawahara et al. 2010, Pantoflicek et al. 2012, Prazak et al. 2013). After considering factors like knowledge of the genomes, accessibility for physiological and biochemical measurements, life span of animals, and economical acceptance, a consensus has been reached (similar as in cardiovascular research) (Zicha and Kunes 1999, Zicha et al. 2012) that laboratory rat is the animal species most suitable for studies of ALF.

After considering other aspects of research, such as demand on technical skills of the investigator and costs of induction of suitable liver injury, the usage of hepatotoxic drugs is increasingly recommended for studies aimed to explore pathophysiology and new treatment approaches in ALF (Butterworth et al. 2009, Tuñon et al. 2009). Furthermore, among all the chemical agents examined, thioacetamide (TAA) is the one most recommended for induction of ALF (Butterworth et al. 2009, Tuñón et al. 2009). TAA has long been known as a hepatotoxicant; its biotransformation to thioacetamide sulfoxide (TAAS) occurs along the cytochrome P-450 (CYP)-dependent pathway (a CYP2E enzyme is mainly involved here), TAAS is subsequently converted to thioacetamide disulfoxide, a toxic reactive metabolite (Koen et al. 2013). These reactive metabolites covalently bind to liver macromolecules and dramatically increase the production of reactive oxygen species which then induce acute centrilobular liver necrosis (Koen et al. 2013).

Surprisingly, a very wide range of intraperitoneal (i.p.) TAA doses was injected (as a single or divided dose) in rats in order to induce ALF; whether the course of TAA-induced ALF is dose-dependent has never been established (Basile et al. 1990, Celik et al. 1999, Pawa and Ali 2004, Anbarasu et al. 2012, Chadipiralla et al. 2012, Farjam et al. 2012, Bautista et al. 2013, Mustafa et al. 2013, Nissar et al. 2013). Interestingly, in studies evaluating hepatoprotective effects of different drugs on TAA-induced hepatotoxicity or new therapeutical approaches for TAA-induced ALF (e.g. bioarteficial liver support systems or hepatocyte transplantation) either Wistar or Lewis rats were used. It has not been established if an outbred rat strain (Wistars) and an inbred rat strain (Lewis rats) exhibit the same sensitivity to TAA with regard to the development and course of ALF (Mehendale 2005, Rahman et al. 2005, Kawahar et al. 2010, Nibourg et al. 2012).

Considering these inconsistencies in TAA usage and also in view of a need for unequivocally characterized and highly reproducible model of rat ALF we sought, first, to investigate the course of ALF when induced by increasing doses of TAA, ranging from 175 to $700 \mathrm{mg} / \mathrm{kg}$ of body weight (BW) i.p. per day (the latter was the highest dose ever reported). Second, we examined whether Wistar and Lewis rats exhibit any differences in the course of ALF in response to increasing TAA doses.

\section{Methods}

\section{Ethical approval, animals and chemicals}

The studies were performed in accordance with guidelines and practices established by the Animal Care and Use Committee of the Institute for Clinical and Experimental Medicine, Prague, which accord with the European Convention on Animal Protection and Guidelines on Research Animal Use. All the animals used in the study were housed in facilities accredited by the Czech Association of Laboratory Animal Care. The experiments were performed in male Wistar and Lewis rats that were purchased from Charles River Laboratories (Anlab, Prague, Czech Republic) at the age of 9 weeks. Before starting experiments the rats were acclimatized in our vivarium during two weeks. The animals were kept on a 12-h/12-h light/dark cycle. Throughout the experiments rats were fed a normal salt, normal protein diet $(0.45 \% \mathrm{NaCl}, 19-21 \%$ protein, SEMED, Prague, Czech Republic) and had free access to tap water. TAA (Sigma, Prague, Czech Republic) was dissolved in physiological saline and the appropriate dose was injected i.p. in 1-ml volume.

\section{Experimental design}

Twenty-four hours before i.p. administration of TAA ("-24 h") rats were anesthetized for 2-3 min with isoflurane, $2 \%$ in air, (Forane, Abbott Laboratories, Prague, Czech Republic) that was administered through a vaporizer, and a blood sample (about $600 \mu \mathrm{l}$ ) was taken from the tail vein, for biochemical analyses (Fuji DriveChem 4000 Analyser). Plasma levels of albumin, 
bilirubin, alanine aminotransferase (ALT) and aspartate aminotransferase (AST) activities and ammonia levels $\left(\mathrm{NH}_{3}\right)$ were determined. Blood samples for the same analyses were also taken 24, 48 and $96 \mathrm{~h}$ after first administration of TAA. The follow-up period in experimental series 1 and 2 was $96 \mathrm{~h}$ and at the end of experiments the surviving animals were killed by an overdose of pentobarbital.

Series 1: Dose-dependent effects of TAA given as a single injection

Freshly prepared TAA was administered i.p. as a single injection on day 0 at 8:00 AM. Since it is well recognized that during ALF development the animals' food and water intake are dramatically reduced, $5 \%$ glucose solution, $2 \mathrm{ml} / 100 \mathrm{~g} \mathrm{BW}$, was administrated intraperitoneally every morning to prevent dehydration. The survival rate was monitored every $8 \mathrm{~h}$, BW was monitored every $12 \mathrm{~h}$ and blood samples were taken as described above. The following experimental groups were investigated (initial $n=20$ in each group):
1. Wistar rats + TAA $175 \mathrm{mg} \cdot \mathrm{kg}^{-1}$
2. Lewis rats + TAA $175 \mathrm{mg} \cdot \mathrm{kg}^{-1}$
3. Wistar rats + TAA $262.5 \mathrm{mg} \cdot \mathrm{kg}^{-1}$
4. Lewis rats + TAA $262.5 \mathrm{mg} \cdot \mathrm{kg}^{-1}$
5. Wistar rats + TAA $350 \mathrm{mg} \cdot \mathrm{kg}^{-1}$
6. Lewis rats + TAA $350 \mathrm{mg} \cdot \mathrm{kg}^{-1}$

Series 2: Dose-dependent effects of TAA given as two injections

Freshly prepared TAA was administered i.p. in two injections, on day 0 at 8:00 AM and 20:00 PM. The total amount of TAA given in individual groups is shown below (initial $n=20$ in each group):

1. Wistar rats + TAA $350 \mathrm{mg} \cdot \mathrm{kg}^{-1}$

2. Lewis rats + TAA $350 \mathrm{mg} \cdot \mathrm{kg}^{-1}$

3. Wistar rats + TAA $525 \mathrm{mg} \cdot \mathrm{kg}^{-1}$

4. Lewis rats + TAA $525 \mathrm{mg} \cdot \mathrm{kg}^{-1}$

5. Wistar rats + TAA $700 \mathrm{mg} \cdot \mathrm{kg}^{-1}$

6. Lewis rats + TAA $700 \mathrm{mg} \cdot \mathrm{kg}^{-1}$

Series 3: Assessment of histological liver changes in response to TAA

In this series of experiments the rats were killed $24 \mathrm{~h}$ after TAA administration, the livers were removed, washed out with physiological saline and transferred into $4 \%$ formaldehyde. The sections stained with hematoxylin-eosin and periodic acid for Schiff reaction (PAS) were examined and evaluated in a blind fashion.
The semi-quantitative histological score as defined by Ishak et al. (1995) was used. This score quantifies the following parameters: A. Periportal or periseptal necrosis, B. Confluent necrosis, C. Focal lytic necrosis, apoptosis and focal inflammation and D. Portal inflammation. For each parameter, the scale of lesions from 0 (absent changes) to 4 (maximal changes) was used, and the final index was calculated as a sum: $\mathrm{A}+\mathrm{B}+\mathrm{C}+\mathrm{D}$.

The following experimental groups were examined ( $\mathrm{n}=8$ in each group):

1. Wistar rats + physiological saline

2. Lewis rats + physiological saline

3. Wistar rats + TAA $350 \mathrm{mg} \cdot \mathrm{kg}^{-1}$ as a single injection

4. Lewis rats + TAA $350 \mathrm{mg} \cdot \mathrm{kg}^{-1}$ as a single injection

5. Wistar rats + TAA $350 \mathrm{mg} \cdot \mathrm{kg}^{-1}$ in two injections

6. Lewis rats + TAA $350 \mathrm{mg} \cdot \mathrm{kg}^{-1}$ in two injections

\section{Statistical analysis}

Statistical analysis of the data was performed using Graph-Pad Prism software (Graph Pad Software, San Diego, California, USA). ANOVA for repeated measurements, followed by Student-Newman-Keuls test, was performed for analysis of changes within the groups. Statistical comparison of other results was made by Student's t-test or one-way ANOVA. Unless noted, values are expressed as mean \pm SEM. A p-value less than 0.05 was considered statistically significant.

\section{Results}

Series 1: Dose-dependent effects of TAA given as a single injection

As shown in Figure 1, administration of TAA in form of a single injection elicited dose-dependent decreases in survival rates in Wistar as well as in Lewis rats. However, Wistar rats exhibited more profound decreases in survival rate compared with Lewis rats. Prior to TAA administration there were no significant differences in BW between Wistar and Lewis rats $(308 \pm 3$ vs. $315 \pm 4 \mathrm{~g}$ ). In both strains significant decreases in BW in response to TAA were noted. However, $48 \mathrm{~h}$ after administration of TAA at 262.5 or $350 \mathrm{mg} \cdot \mathrm{kg}^{-1}$, Wistar rats exhibited significantly greater decreases in $\mathrm{BW}$ compared with Lewis rats $(-25 \pm 3$ and $-27 \pm 3$ vs. $-14 \pm 2$ and $-12 \pm 2 \mathrm{~g}, \mathrm{p}<0.05$ in both cases). 

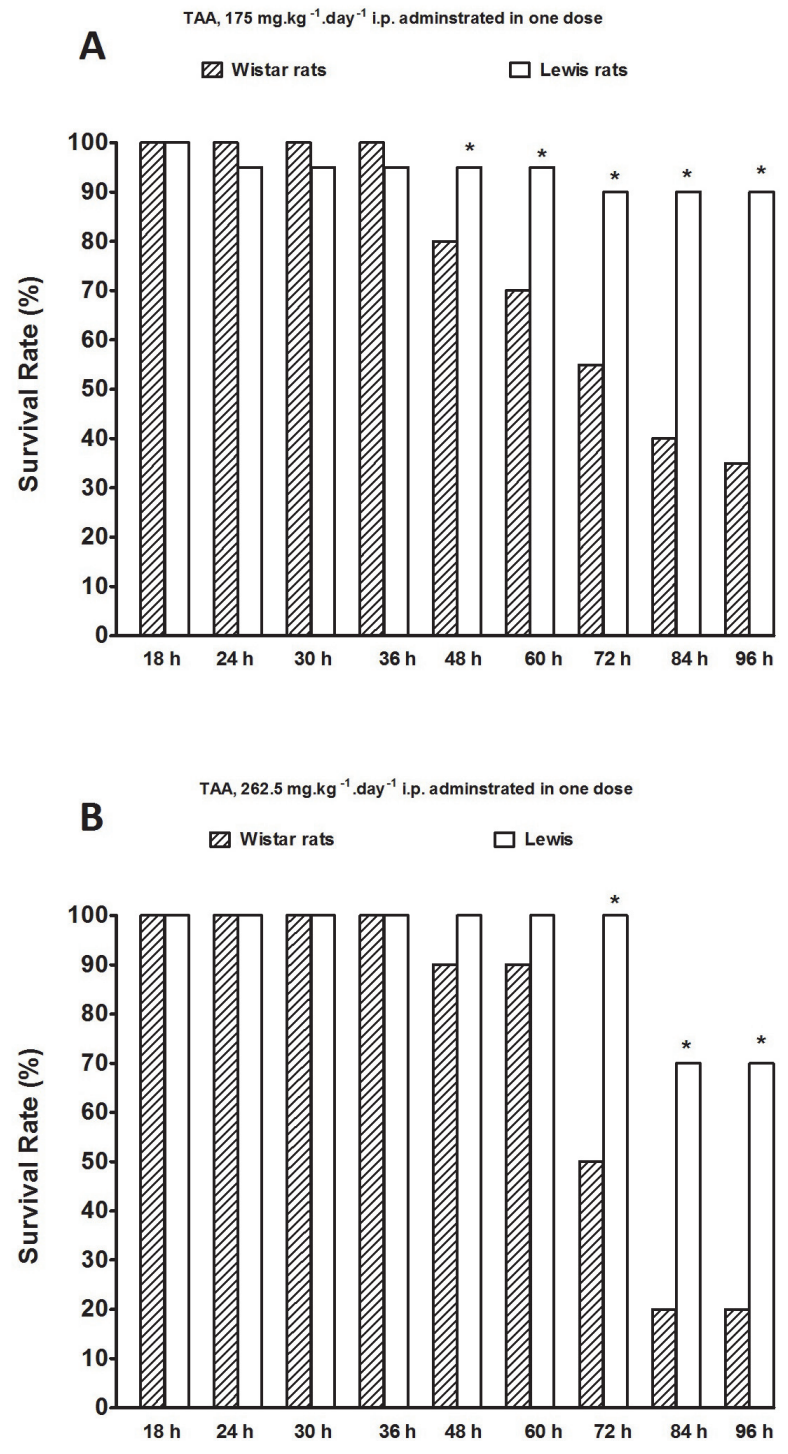

C

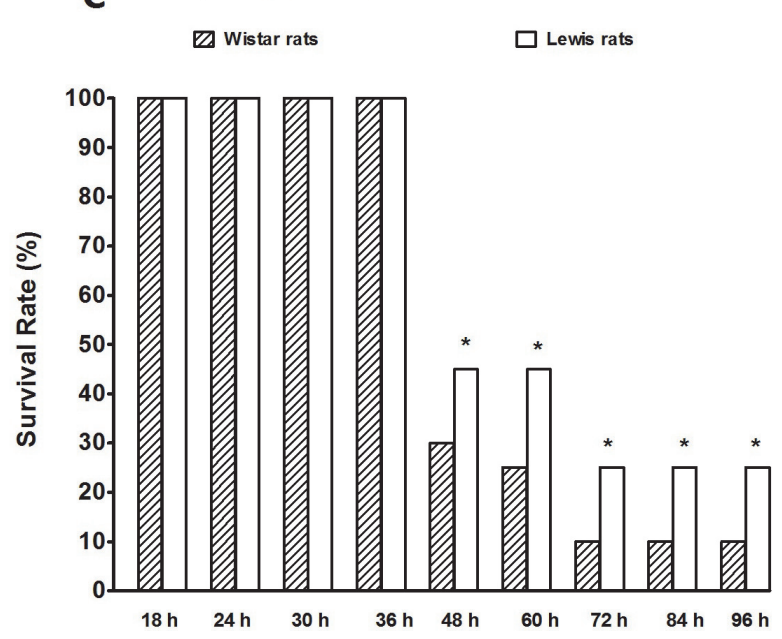

Fig. 1. Survival rates after intraperitoneal (i.p.) administration of $175 \mathrm{mg} \cdot \mathrm{kg}^{-1} \cdot \mathrm{day}^{-1}$ (A), $262.5 \mathrm{mg} \cdot \mathrm{kg}^{-1} \cdot \mathrm{day}^{-1}$ (B) and $350 \mathrm{mg} \cdot \mathrm{kg}^{-1} \cdot \mathrm{day}^{-1}$ (C) of thioacetamide (TAA) ${ }^{*} \mathrm{P}<0.05$ Lewis versus Wistar rats at the same time point.
As shown in Figure 2, baseline values (" $-24 \mathrm{h")}$ of plasma ALT activity (international units per liter plasma, IU/l) and plasma bilirubin levels did not significantly differ between Wistar and Lewis rats $(33 \pm 4$ vs. $28 \pm 4 \mathrm{IU} / \mathrm{l}$, and $9.56 \pm 1.41$ vs. $10.12 \pm 1.33 \mu \mathrm{mol} / \mathrm{l}$, respectively). All three doses of TAA caused significant increases in ALT activities and plasma bilirubin levels in Wistar as well as Lewis rats, with maximum levels observed $48 \mathrm{~h}$ after TAA administration, and these increases were greater in Lewis rats compared with Wistar rats (Fig. 2). Changes in AST showed a response pattern similar as that for ALT, and because ALT is a more specific marker for liver function changes, AST values are not shown.

As shown in Figure 3, there were no significant differences in baseline plasma $\mathrm{NH}_{3}$ levels between Wistar and Lewis rats. Each of the three doses of TAA caused significant increases in plasma $\mathrm{NH}_{3}$ levels, however, the changes in Wistar rats were more prominent than in Lewis rats. There were no significant differences in baseline plasma albumin levels between Wistar and Lewis rats $(29.6 \pm 0.9$ vs. $31.5 \pm 1.1 \mathrm{~g} / \mathrm{l})$ and no significant alterations were noticed after TAA, throughout the observation period.

Series 2: Dose-dependent effects of TAA given as two injections

As shown in Figures 4A-C, TAA administered in two injections at double total doses compared to Series 1 dramatically decreased survival rate so that no animal survived $96 \mathrm{~h}$, in any of the dose groups. After application of high doses of TAA (525 and $700 \mathrm{mg} \cdot \mathrm{kg}^{-1}$ ) all rats succumbed within first $48 \mathrm{~h}$. Again, Wistar rats exhibited significantly lower survival rate compared with Lewis rats at the same time point.

As shown in Figures 4D-F, TAA administration in two injections on day 0 elicited marked increases in plasma $\mathrm{NH}_{3}$ levels already after $24 \mathrm{~h}$, the changes were significantly greater in Wistar compared with Lewis rats. Since the changes in plasma ALT and AST activities and plasma bilirubin levels revealed a pattern similar as that observed with $\mathrm{NH}_{3}$ levels the respective data are not shown.

Series 3: Assessment of histological liver changes in response to TAA

Representative slices of liver tissue (stained with PAS) from vehicle-treated (physiological saline i.p.) Wistar (A) and Lewis (B) rats, and from Wistar and 
A TAA, $175 \mathrm{mg}^{\mathrm{kg}}{ }^{-1}$.day ${ }^{-1}$ i.p. adminstrated in one dose

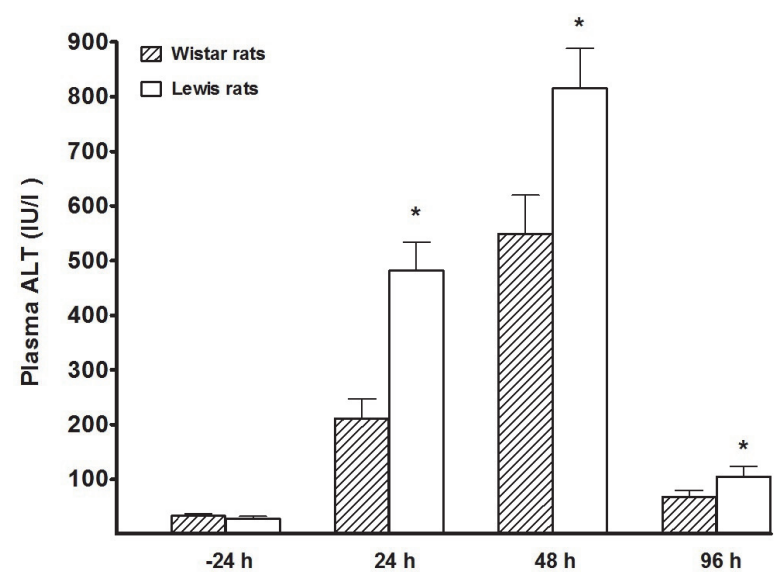

B

TAA, $262.5 \mathrm{mg} \mathrm{kg}^{-1}$. day $^{-1} \mathrm{i} . \mathrm{p}$. adminstrated in one dose

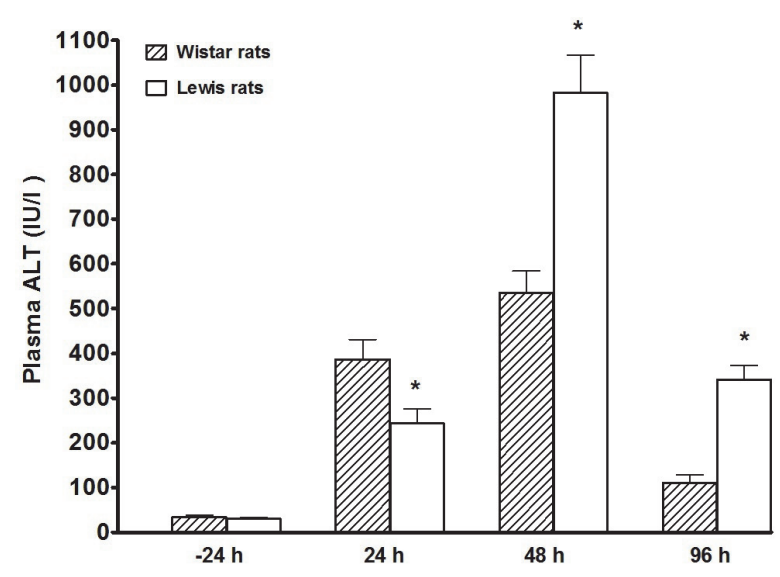

C

TAA, $350 \mathrm{mg}^{. \mathrm{kg}^{-1} . \text { day }}{ }^{-1} \mathrm{i} . \mathrm{p}$. adminstrated in one dose

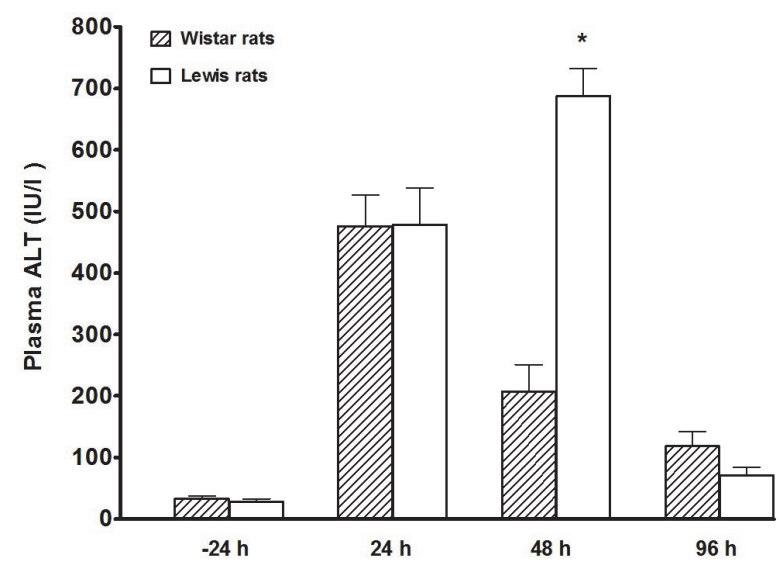

D

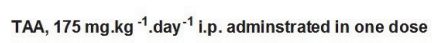

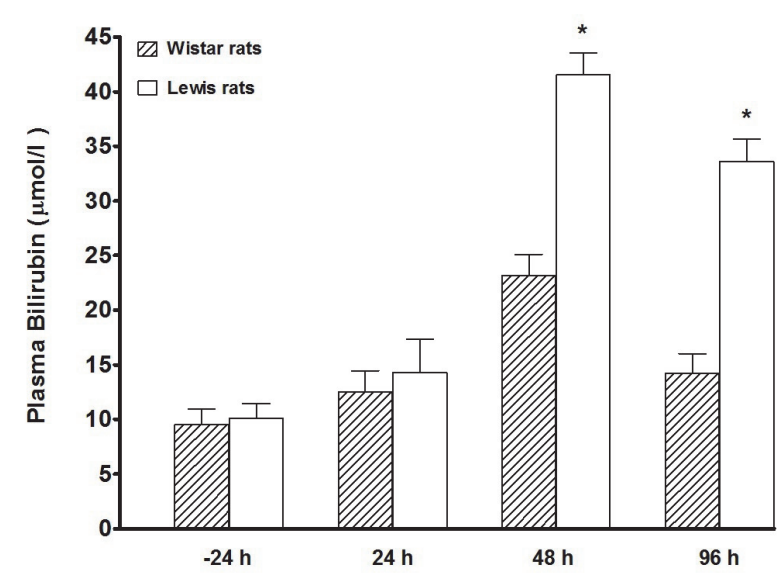

E

TAA, $262.5 \mathrm{mg} \mathrm{kg}^{-1}$. day $^{-1}$ i.p. adminstrated in one dose

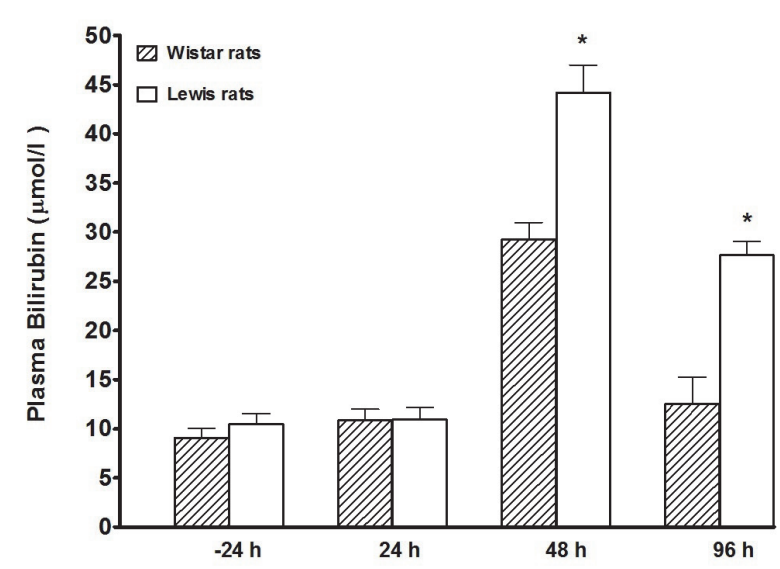

F

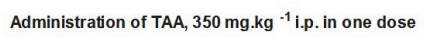

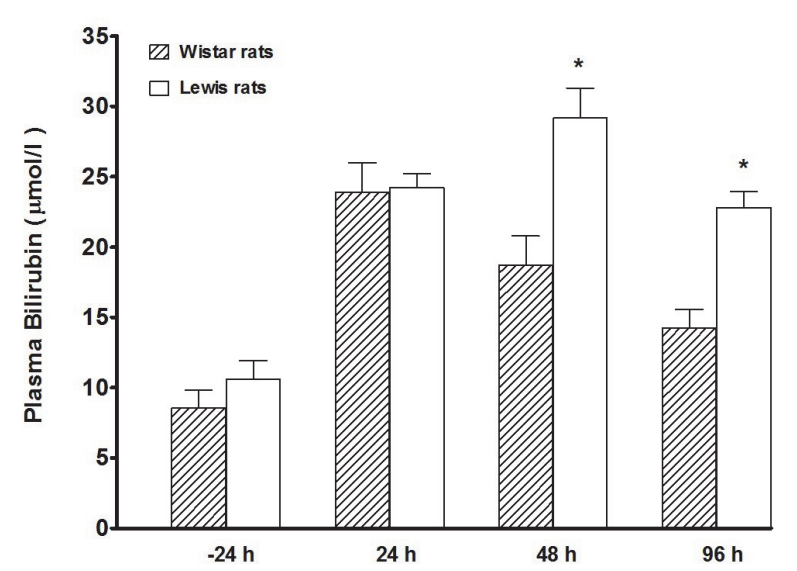

Fig. 2. Changes in plasma alanine aminotransferase (ALT) activities (A to $\mathbf{C}$ ) and plasma bilirubin levels (D to $\mathbf{F}$ ) in response to increasing doses of thioacetamide (TAA) given as a single injection. ${ }^{*} \mathrm{P}<0.05$ Lewis versus Wistar rats at the same time point. 
A

TAA, 175 mg.kg $^{-1}$.day ${ }^{-1}$ i.p. adminstrated in one dose

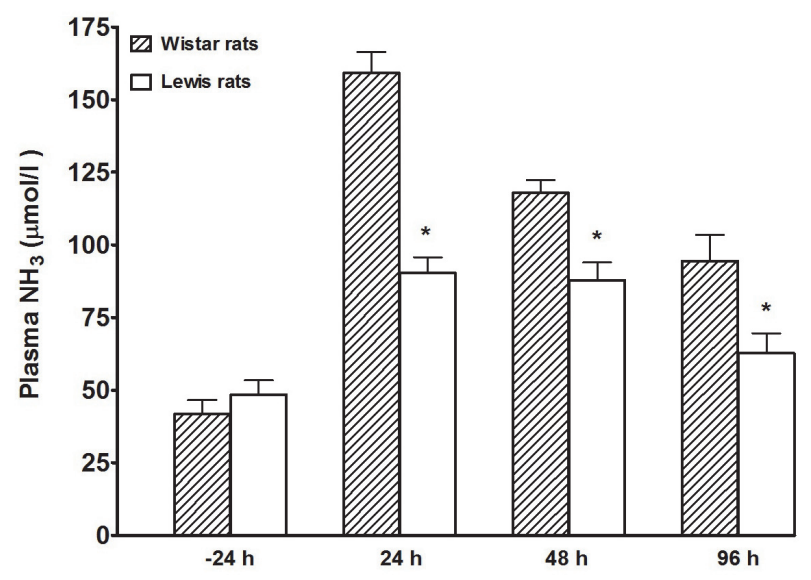

B

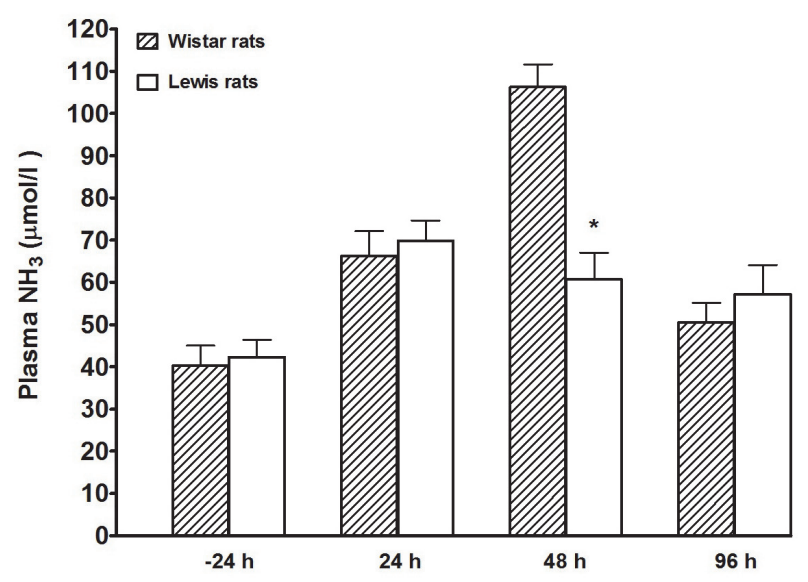

C

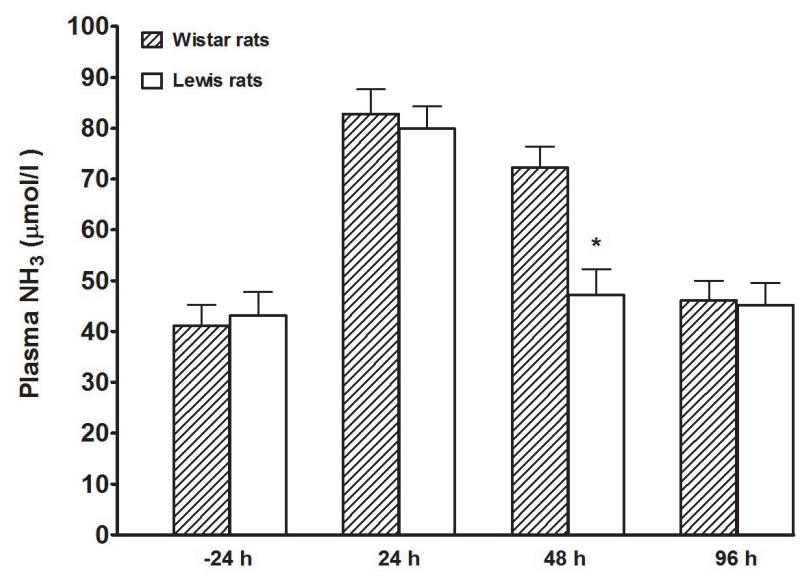

Fig. 3. Changes in plasma ammonia $\left(\mathrm{NH}_{3}\right)$ levels after intraperitoneal (i.p.) administration of $175 \mathrm{mg} \cdot \mathrm{kg}^{-1} \cdot \mathrm{day}^{-1}$ (A), $262.5 \mathrm{mg} \cdot \mathrm{kg}^{-1} \cdot \mathrm{day}^{-1} \quad$ (B) and $350 \mathrm{mg} \cdot \mathrm{kg}^{-1} \cdot \mathrm{day}^{-1} \quad$ (C) of thioacetamide (TAA). ${ }^{*} \mathrm{P}<0.05$ Lewis versus Wistar rats at the same time point.
Lewis rats treated with TAA at $350 \mathrm{mg} \cdot \mathrm{kg}^{-1}$ in a single injection $(\mathrm{C}$ and $\mathrm{D})$, and from Wistar and Lewis rats treated with TAA at $350 \mathrm{mg} \cdot \mathrm{kg}^{-1}$ given in two injections (E and F) are shown in Figure 5. In general, Wistar rats showed relatively more pronounced abnormalities of the liver parenchyma: dystrophic changes of hepatocytes, and congestion and diffuse centrilobular hemorrhagic necrosis with sporadic formation of bridging necrosis. Vehicletreated Wistar and Lewis rats revealed normal liver parenchyma. Histological scoring revealed no damage in the liver parenchyma of vehicle-treated Wistar and Lewis rats (score 0 in both cases). Wistar rats treated with TAA $350 \mathrm{mg} \cdot \mathrm{kg}^{-1}$ (single injection) showed significantly higher liver injury compared with Lewis rats (histological score $6.1 \pm 0.37$ vs. $3.67 \pm 0.49, \mathrm{p}<0.05$ ). Treatment with TAA at $350 \mathrm{mg} \cdot \mathrm{kg}^{-1}$ applied in two injections further impaired liver injury in Wistar as well as in Lewis rats, the histological score was then still significantly higher in Wistar compared with Lewis rats $(7.83 \pm 0.31$ vs. $5.17 \pm 0.47, \mathrm{p}<0.05)$.

\section{Discussion}

The first important finding of the present study is that increasing doses of TAA elicited dose-dependent decreases in survival rate in Wistar as well as in Lewis rats, and that in both rat strains the highest dose compatible with survival of at least some of animals until the end of the follow-up period was $350 \mathrm{mg} \cdot \mathrm{kg}^{-1}$ given as a single injection. Of special interest is that administration of the same amount of TAA in two injections instead of a single one caused more profound decreases in survival rate so that no animals in either strain group survived beyond $72 \mathrm{~h}$ (compare the data of Fig. 1C and Fig. 4A). Furthermore, administration of TAA at doses of 525 and $700 \mathrm{mg} \cdot \mathrm{kg}^{-1}$ elicited striking decreases in survival rate and neither of Wistar or Lewis rat survived $48 \mathrm{~h}$. The pattern of survival rate was similar with both these doses, indicating that the maximal hepatotoxic effect was already reached with the total dose of $525 \mathrm{mg} \cdot \mathrm{kg}^{-1}$ administered in two injections. TAA administration at each dose used was accompanied by progressing increases in plasma bilirubin levels, ALT and AST activities and plasma $\mathrm{NH}_{3}$ concentrations, with maximum augmentation just before the onset of dying of rats. All these changes are characteristic for ALF, suggesting that TAA administration truly induces a condition resembling the ALF in human beings (Lee 2012, Tritto et al. 2012). A consensus has been achieved 
that animal models for untreated ALF should exhibit some percentage of spontaneous survivors. It was reasoned that possible beneficial effects of new therapeutical approaches should be evaluated under conditions resembling human disease (Butterworth et al.
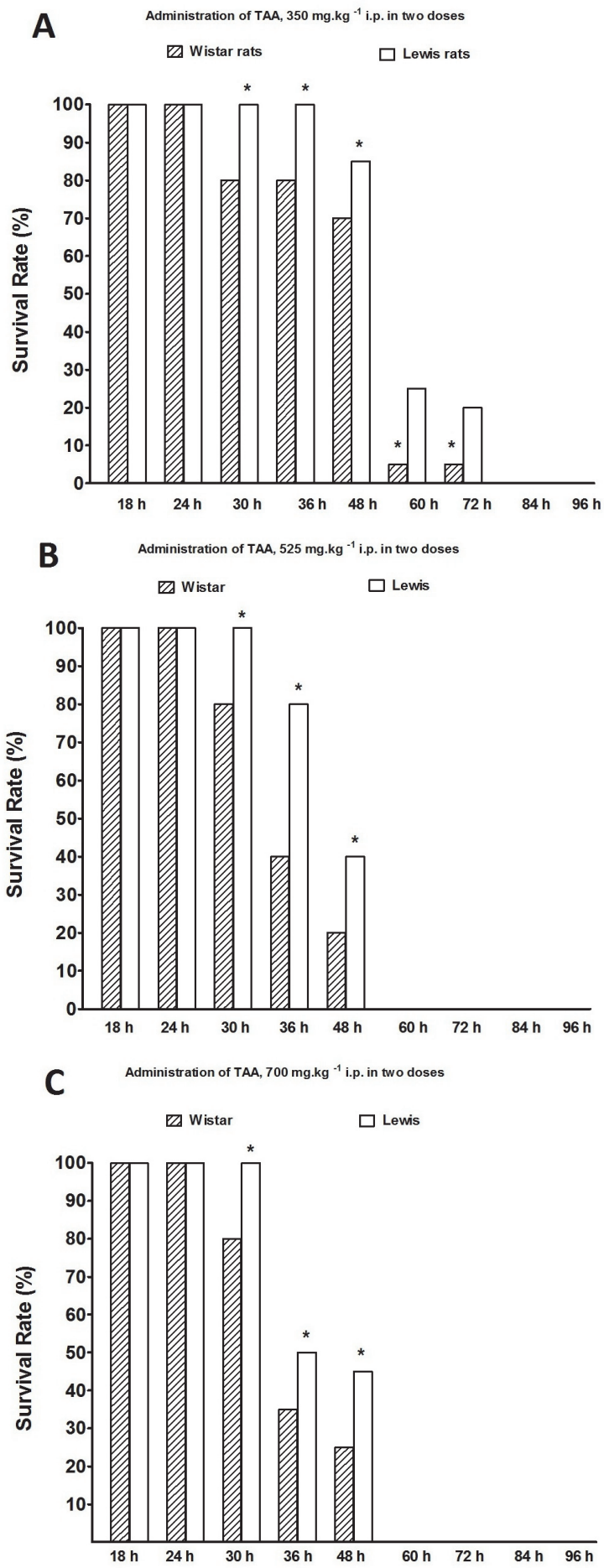

2009, Tuñón et al. 2009). Taken all these facts into consideration and based on our current results, we suggest that the optimal TAA dose for induction of ALF in rats equals $350 \mathrm{mg} \cdot \mathrm{kg}^{-1}$ administered i.p. as a single injection.

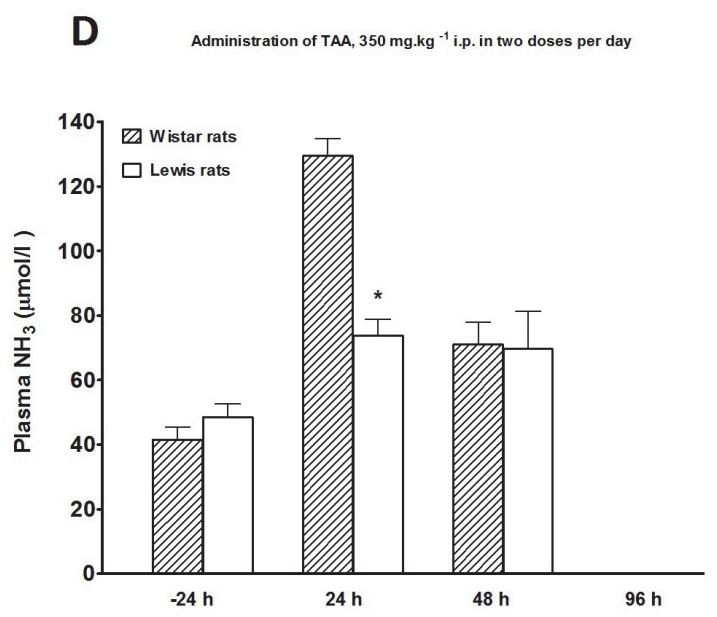

E

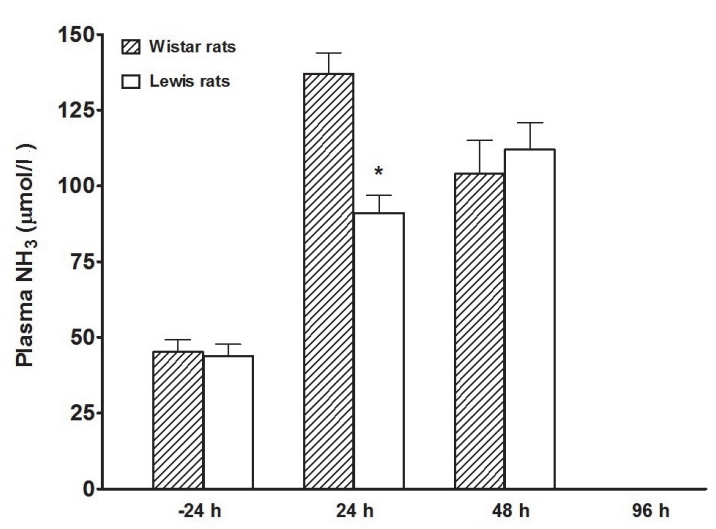

F Administration of TAA, $700 \mathrm{mg}^{-k^{-1}}{ }^{1}$ i.p. in two doses per day

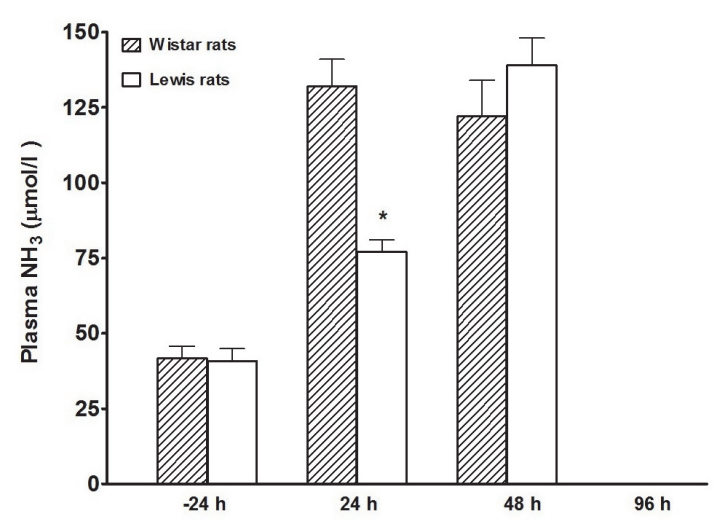

Fig. 4. Survival rates (A to $\mathbf{C}$ ) and plasma ammonia $\left(\mathrm{NH}_{3}\right)$ levels ( $\mathbf{D}$ to $\mathbf{F}$ ) as affected by increasing doses of thioacetamide (TAA) given in two injections per day. ${ }^{*} \mathrm{P}<0.05$ Lewis versus Wistar rats at the same time point. 

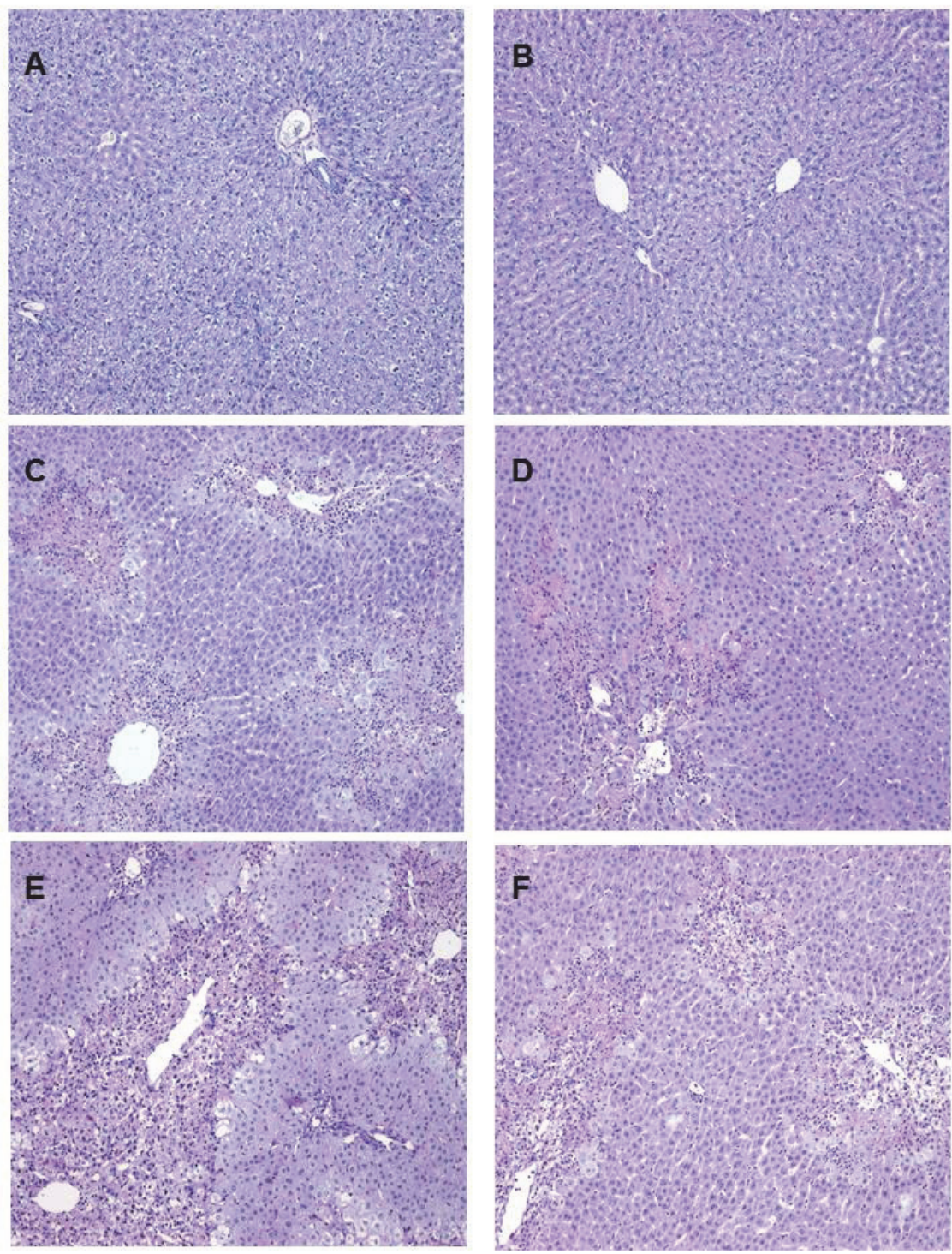

Fig. 5. Liver damage of Wistar and Lewis rats after exposure to thioacetamide (TAA): vehicle-treated Wistar (A) and Lewis (B) rats; Wistar (C) and Lewis (D) rats treated with (TAA) at $350 \mathrm{mg} \cdot \mathrm{kg}^{-1}$ given in one injection; Wistar (E) and Lewis (F) rats treated with TAA at 350 $\mathrm{mg} . \mathrm{kg}^{-1}$ given in two injections. Brief histological description: A (Wistar rats): Liver parenchyma with normal liver architecture (stained with periodic acid for Schiff reaction (PAS), magnification 40x). B (Lewis rats): Liver parenchyma without pathological changes, (PAS, 40x). C (Wistar rats): Post-treatment confluent coagulative necrosis involving the perivenular and mid-zones, (PAS, 40x). D (Lewis rats): Post-treatment perivenular necrosis with sporadic bridging and focal necrosis, (PAS, 40x). E (Wistar rats): Posttreatment bridging privenular necrosis with slight sinusoidal congestion. Sporadic monocellular necrosis, (PAS, 40x). $\mathbf{F}$ (Lewis rats): Post-treatment focal perivenular necrosis with slight lymphocytosis. Sporadic monocellular necrosis, (PAS, 40x).
In this context, it is worthwhile to briefly discuss some other chemical models of ALF; it should be mentioned that almost 25 years ago certain criteria that an ideal animal model of ALF should satisfy were suggested (Terblanche and Hickman 1991): a) reversibility, i.e. that induced liver failure should be potentially reversible; b) reproducibility, i.e. that degree of liver damage should be standardized, especially within the major endpoint which is the death of the animal; c) death cause, i.e. that death should be a direct result of the insult to the liver; d) therapeutic window, i.e. that sufficient time should available between the insult and the death; e) minimum hazard to personnel, i.e. that the toxin should present minimal risk to investigators.

In consideration of those criteria the following chemical agents have been extensively used in the development of animal models of ALF.

\section{Carbon tetrachloride $\left(\mathrm{CCl}_{4}\right)$}

The hepatoxic effects of $\mathrm{CCl}_{4}$ have been known for many years (Hubner et al. 1965), however its use is infrequent because liver damage induced with this compound is poorly reproducible and exhibits high species variation (Shi et al. 1997). In addition, it was demonstrated that $\mathrm{CCl}_{4}$ administration simultaneously produces liver damage and liver regeneration (Weber et al. 2003, Taniguchi et al. 2004). Moreover, administration of $\mathrm{CCl}_{4}$ does not cause massive hepatic necrosis, which is characteristic for human ALF. Effects of $\mathrm{CCl}_{4}$ intoxication are limited (as observed also in humans) to encephalopathy and late stage hepatic coma (Tuñón et al. 2009). Furthermore, $\mathrm{CCl}_{4}$ is not entirely metabolized in the liver and non-metabolized toxins substantially alter and damage the lung and the kidney (Newsome et al. 2000, Tunón et al. 2009). Finally, $\mathrm{CCl}_{4}$ manipulation presents a significant hazard to laboratory staff. 


\section{Acetaminophen (APAP)}

This commonly used drug that can elicit liver damage; even though an effective antidote (N-acetylcysteine) has been available for long time, APAP overdosage is the most common cause of druginduced ALF in industrialized word (Larson 2007). Under normal conditions APAP undergoes biotransformation in the liver by a combination of glucuronidation and sulphation, followed by renal excretion. When an excess APAP is present, these detoxifying pathways are saturated and APAP is metabolized by the cytochrome P450 (CYP-450) oxidase enzyme system, leading to the synthesis of N-acetyl-pbenzoquinoneimine, an extremely toxic electrophile (Jaeschke et al. 2013). APAP hepatotoxicity varies, depending on the variable activity of CYP-450 pathway. For instance, it is potentiated by inducers of CYP-450 system, such as phenobarbitone. In addition, APAP overdosage triggers an innate immune response (Jaeschke et al. 2013, Williams et al. 2014), and is also nephrotoxic, cardiotoxic and induces acute lung injury (Baudouin et al. 1995, Eguia and Materson 1997, Jaeschke et al. 2013). Furthermore, APAP overdosage in animals might induce a sudden death due to uncontrolled methaemoglobinemia (Jaeschke et al. 2013). Taken together, the major problem of APAP-induced ALF is its extreme variability and numerous unpredictable sideeffects of the drug.

\section{D-Galactosamine (D-Gal)}

It is an amino sugar which, when metabolized along the galactose pathway in the liver, leads to depletion of uridine nucleoides and hepatic transcriptional blockade, with consequent metabolic alterations and hepatic necrosis (Newsome et al. 2000). A major advantage of this model is that it displays a majority of characteristics observed in human ALF, such as increases in liver enzyme activities, plasma $\mathrm{NH}_{3}$ concentrations, hypoglycemia, coma, and an increase in intracranial pressure (Keppler et al. 1968). However, the model exhibits also some disadvantages. It has been shown that the course of D-Gal-induced ALF is substantially altered by anesthesia (Newsome et al. 2000). A reproducible model of D-Gal-induced ALF has been established in large animals (pigs), but substantial variability was demonstrated in rats and mice: these species showed considerable resistance to D-Gal until extremely high doses were employed (Leist et al. 1996, Newsome et al. 2000). Furthermore, the interval between administration of D-Gal and the death of the animal varies considerably (Rahman and Hodgson 2000). Finally, since the model of D-Gal-induced ALF is used in large animals, the cost of a relatively large quantity of D-Gal needed is an important burden.

Overall, considering the criteria for optimal animal model of ALF (Terblanche and Hickman 1991), the information from aforementioned studies employing chemical agents other than TAA to induce ALF, and our present results, we are convinced that TAA-induced ALF is the optimal model which fulfills all the criteria mentioned above and resembles the course of ALF observed in humans (Bernal and Wendon 2013). Obviously, this the reason why the model of TAAinduced ALF is now increasingly employed for experimental studies, especially those evaluating new therapeutic approaches for the treatment of ALF, just to name a newest study exploring the potential protective impact of antioxidants on the course of ALF (Mustafa et al. 2013).

The second major finding of the present study is that Wistar rats are more sensitive to TAA-induced liver damage resembling ALF when compared with Lewis rats. This finding was unexpected because our original hypothesis was that outbred rat strain (Wistars) should be more resistant to TAA hepatotoxicity than an inbred rat strain (Lewis rats). We cannot offer any satisfactory explanation for different sensitivity of Wistar and Lewis rats to TAA administration. The reason was not different basal liver function because the pretreatment values of biochemical parameters related to liver function, such as ALT and AST activities, plasma bilirubin, $\mathrm{NH}_{3}$ and albumin levels, were not significantly different between Wistar and Lewis rats. However, it is conceivable that different genetic background determines the course of the phase I of biotransformation of xenobiotics in the hepatocytes, the process which is mediated by CYP pathway (Mehendale 2005, Koen et al. 2013); this could be responsible for the different sensitivity. Obviously, additional studies that are beyond the scope of the present project are necessary to address this issue.

We saw that 48 and $96 \mathrm{~h}$ after TAA administration Lewis rats exhibited significantly higher values for biochemical markers of liver injury, such as plasma ALT and AST activities and plasma bilirubin levels, as compared with Wistar rats. At the same time, Lewis rats showed a significantly better survival rate as compared with Wistar rats. Remarkably, we observed that the animals with the highest plasma $\mathrm{NH}_{3}$ concentrations 
measured $24 \mathrm{~h}$ after TAA administration died first. However, one should consider that the elevated biochemical markers of liver injury in Lewis rats (higher than in Wistar rats) observed after TAA administration is a simple (quasi-negative) consequence or "a side-effect" of the improved survival rate in these animals. This phenomenon is comparable to observations in rats that underwent 5/6 renal ablation (NX), a model of chronic kidney disease (CKD). It was seen that 5/6 NX rats under treatment exhibited only temporary attenuation of proteinuria, an important prognostic factor of CKD (Bidani et al. 2013), in comparison with untreated rats. The reason was that untreated animals with the highest proteinuria died first, which resulted in a paradoxical improvement in the mean proteinuria level in this group. (Vaněčková et al. 2012, Čertíková Chábová et al. 2014, Kujal et al. 2014).

In this context, it is important to acknowledge that a search for optimal animal model for ALF is still ongoing and factors such as reproducibility, adequate animal size, cost of animals, an appropriate "therapeutic window" (time required for treatment, between the insult and death of animals), minimal risk to investigators etc. must be considered. Currently, surgical models of ALF in large animals are preferred (e.g. devascularization of the liver in pigs) because of high reproducibility; moreover, large size of animals enables evaluation of different bioartefical liver support systems (Butterworth et al. 2009, Ryska et al. 2009, 2012, Tuñón et al. 2009, Prazak et al. 2013). However, the large size of animals is also a disadvantage because experiments are extremely costly (housing and handling of animals, induction of ALF requires a team of investigators). Therefore, chemical agents, such acetaminophen, galactosamine, carbon tetrachloride and many others (Mehendale 2005, Butterworth et al. 2009, Tuñon et al. 2009) are used in small laboratory animals (rats and mice) for induction of ALF. After consideration of the aforementioned aspects, especially of the reproducibility of ALF induction and safety for investigators, the use of TAA is at present most recommended (Butterworth et al. 2009, Tuñón et al. 2009). However, as has already been discussed in the introduction section, even though this model has been used for more than 30 years (Basile et al. 1990, Celik et al. 1999, Pawa et al. 2004, Rahman et al. 2005, Anbarasu et al. 2012, Chadiprialla et al. 2012, Farjam et al. 2012, Bautista et al. 2013), some limitations in TAA application for induction of ALF were not appropriately addressed. This was the rationale for undertaking our present study.

\section{Limitations of the study}

One important limitation of this study is that neither the changes in plasma and liver concentrations of the inflammatory cytokines (such as e.g. tumor necrosis factor (TNF- $\alpha$ ), interleukin-1 $\beta$ etc.) nor tissue oxidative stress markers were determined. Second, important information about pharmacokinetics is missing, specifically, plasma levels of TAA and TASO, a major hepatotoxic product of biotransformation of TAA, were not determined. Third, the analyses of CYP-dependent drug-metabolizing pathway (such as expression and activity of CYP2E enzyme) were not performed. These limitations inevitably narrow our insight into the complex mechanisms responsible for the course of TAA-induced ALF in Wistar and Lewis rats.

In conclusion, the results of the present study show that in the rat, the optimal dose for induction of ALF is $350 \mathrm{mg} \cdot \mathrm{kg}^{-1}$ administered i.p. as a single injection. Second, our data show that Wistar rats are more susceptible to develop TAA-induced ALF than are Lewis rats. Collectively, our present findings provide a sound methodological background for experimental studies aimed at evaluation of pathophysiology and development of new approaches in the therapy of ALF.

\section{Conflict of Interest}

There is no conflict of interest.

\section{Acknowledgements}

This study was supported by Ministry of Health of the Czech Republic within the project for the development of research organization 00023001 (IKEM) and MO 2012 $(\mathrm{CMH})$ - institutional support. The Center for Experimental Medicine (IKEM) received financial support from the European Commission within the Operational Program Prague-Competitiveness; project "CEVKOON" (\#CZ.2.16/3.1.00/22126).

\section{References}

ANBARASU C, RAJKOPOOR B, BHAT KS, GIRIDHARAN J, ARUL AMUTHAN A, SATISH K: Protective effect of Pisonia aculeate on thioacetamide induced hepatotoxicity in rats. Asian Pac J Trop Biomed 2: 511-515, 2012. 
BAÑARES R, CATALINA MV, VAQUERO J: Liver support systems: will they reach prime time? Curr Gastroenterol Rep 15: 312-319, 2013.

BASILE AS, PANNELL LP, JAOUNI T, GAMMAL SH, FALES HM, JONES EA, SKOLNICK P: Brain concentrations of benzodiazepines are elevated in an animal model of hepatic encephalopathy. Proc Natl Acad Sci 87: 5263-5267, 1990.

BAUDOUIN SV, HOWDLE P, O'GRADY JG, WEBSTER NR: Acute lung injury in fulminant hepatic failure following paracetamol poisoning. Thorax 50: 399-402, 1995.

BAUTISTA M, DEL RIO MAG, BENEDÍ J, SÁNCHEZ-REUS MI, MORALES-GONZÁLEZ JA, TÉLLEZ-LÓPEZ AM, LÓPEZ-OROZCO M: Effect of dichloromethylene diphsphonate on liver regeneration following thioacetamide-induced necrosis in rats. World J Hepatol 27: 379-386, 2013.

BERG CL, MERION RM, SHEARON TH, OLTHOFF KM, BROWN RS JR, BAKER TB, EVERSON GT, HONG JC, TERRAULT N, HAYASHI PH, FISHER RA, EVERHART JE: Liver transplant recipient survival benefit with living donation in the model for end-stage liver disease allocation era. Hepatology 54: 1313-1321, 2011.

BERNAL W, WENDON J: Acute liver failure. N Engl J Med 369: 2525-2534, 2013.

BIDANI AK, POLICHNOWSKI AJ, LOUTZENHISER R, GRIFFIN KA: Renal microvascular dysfunction, hypertension and CKD progression. Curr Opin Nephrol Hypertens 22: 1-9, 2013.

BONAVITA AG, QUARESMA K, COTTA-DE-ALMEIDA V, PINTO MA, SARAIVA RM, ALVES LA: Hepatocyte xenotransplantation for treating liver disease. Xenotransplantation 17: 181-187, 2010.

BUTTERWORTH RF, NORENBERG MD, FELIPO V, FERENCI P, ALBRECTH J, BLEI AT: Experimental models of hepatic encephalopathy: ISHEN guidelines. Liver Int 29: 783-788, 2009.

CELIK T, UZBAY IT, CINAR K, BOZKAYA H, UZUNALIMOGLU O, YURDAYDM C: Combination treatment of hepatic encephalopathy due to thioacetamide-induced fulminant hepatic failure in the rat with benzodiazepine and opioid receptor antagonists. $J$ Hepatol 31: 880-886, 1999.

ČERTÍKOVÁ CHÁBOVÁ V, VERNEROVÁ Z, KUJAL P, HUSKOVÁ Z, ŠKAROUPKOVÁ P, TESAŘ V, KRAMER HJ, KOMPANOVSKA-JEZIERSKA E, WALKOWSKA A, SADOWSKI J, ČERVENKA L, VANĚČKOVÁ I: Addition of $\mathrm{ET}_{\mathrm{A}}$ receptor blockade increases renoprotection provided by renin-angiotensin system blockade in 5/6 nephrectomized Ren-2 transgenic rats. Life Sci: in press 2014.

CHADIPIRALLA K, REDDANNA P, CHINTA RM, REDDY PVB: Thioacetamide-induced fulminant hepatic failure induces cerebral mitochondrial dysfunction by altering the electron transport chain complexes. Neurochem Res 37: 59-68, 2012.

EGUIA L, MATERSON BJ: Acetaminophen-related acute renal failure without fulminant liver failure. Pharmacotherapy 17: 363-370, 1997.

FARJAM M, DEHDAB P, ABBASSNIA F, MEHRABANI D, TANIDEH N, PAKBAZ S, IMANIEH MH: Thioacetamide-induced acute hepatic encephalopathy in rat: behavioral, biochemical and histological changes. Iran Red Crescent Med J 14: 164-170, 2012.

HUBNER G: Ultrastructural liver damage caused by direct action of carbon tetrachloride in vivo and in vitro. Virchows Arch Pathol Anat Physiol Klin Med 339: 187-197, 1965.

ISHAK K, BAPTISTA A, BIANCHI L, CALLEA F, DE GROOTE J, GUDAT F, DENK H, DESMET V, KORB G, MACSWEEN RNM, PHILLIPS MJ, PORTAMNN BG, POULSEN H, SCHEUER PJ, SCHMID M, THALER H: Histological grading and staging of chronic hepatitis. J Hepatol 22: 696-699, 1995.

JAESCHKE H, WILIAMS CD, MCGILL MR, XIE Y, RAMACHANDRAN A: Models of drug-induced liver injury for evaluation of phytotherapeutics and other natural products. Food Chem Toxicol 55: 279-289, 2013.

KUJAL P, ČERTÍKOVÁ CHÁBOVÁ V, ŠKAROUPKOVÁ P, HUSKOVÁ Z, VERNEROVÁ Z, KRAMER HJ, WALKOWSKA A, KOMPANOWSKA-JEZIERSKA E, SADOWSKI J, KITADA K, NISHIYAMA A, HWANG SH, HAMMOCK BD, IMIG JD, ČERVENKA L: Inhibition of soluble epoxide hydrolase is renoprotective in 5/6 nephrectomized Ren-2 transgenic hypertensive rats. Clin Exp Pharmacol Physiol 41: 227-237, 2014.

KAWAHARA T, TOSO C, DOUGLAS DN, NOURBAKHSH M, LEWIS JT, TYRRELL DL, LUND GA, CHURCHILL TA, KNETEMAN NM: Factors affecting hepatocyte isolation, engrafment, and replication in an in vivo model. Liver Transpl 16: 974-982, 2010. 
KEPLER D, LESCH R, REUTTER W, DECKER K: Experimental hepatitis induced by D-galactosamine. Exp Mol Pathol 9: 279-290, 1968.

KIM WR, THERNEAU TM, BENSON JT, KREMERS WK, ROSEN CB, GORES GJ, DICKSON ER: Deaths on the liver transplant waiting list: an analysis of competing risks. Hepatology 43: 345-351, 2006.

KIM HJ, LARSON JJ, LIM YS, KIM WR, PEDERSEN RA, THERNEAU TM, ROSEN CB: Impact of MELD on Waitlist outcome of retransplant candidates. Am J Transplant 10: 2652-2657, 2010.

KOEN YM, SARMA D, HAJOVSKY H, GALEVA NA, WILIAMS TD, STAUDINGER JL, HANZLIK RP: Protein targets of thioacetamide metabolites in rat hepatocytes. Chem Res Toxicol 26: 564-574, 2013.

LARSON AM: Acetaminophen hepatoxicity. Clin Liver Dis 11: 525-548, 2007.

LEE WM: Acute liver failure. Semin Respir Crit Care Med 33: 36-45, 2012.

LEIST M, GANTNER F, KUNSTLE G, BOHLINGER I, TIEGS G, BLUETHMANN H, WENDEL A: The 55-kD tumor necrosis factor receptor and CD95 independently signal murine hepatocyte apoptosis and subsequent liver failure. Mol Med 2: 109-124, 1996.

MEHENDALE HM: Tissue repair: an important determinant of final outcome of toxicant-induced injury. Toxicol Pathol 33: 41-51, 2005.

MUSTAFA HN, AWDAN SAE, HEGAZY GA: Protective role of antioxidants on thioacetamide-induced acute hepatic encephalopathy: biochemical and ultrastructural study. Tissue Cell 45: 350-362, 2013.

NEWSOME PN, PLEVRIS JN, NELSON LJ, HAYES PC: Animal models of fulminant hepatic failure: a critical evaluation. Liver Transpl 6: 21-31, 2000.

NIBOURG GAA, CHAMULEAU RAFM, VAN DER HOEVEN TV, MAAS MAW, RUITER AFC, LAMERS WH, ELFERINK RPJO, VAN GULIK TM, HOEKSTRA R: Liver progenitor cell line hepaRG differentiated in a bioarteficial liver effectively supplies liver support to rats with acute liver failure. PLos ONE 7: e38778, 2012.

NISSAR AU, FARRUKH MR, KAISER PJ, RAFIG RA, AFNAN Q, BHUSHAN S, ADIL HS, SUBHASH BC, TASDUG SA: Effect of N-acetylcysteine, an organosulfur compound from Allium plants, on experimentally induced hepatic prefibrogenic events in Wistar rat. Phytomedicine 20: 828-833, 2013.

PANTOFLICEK T, KOBLIHOVA E, RYSKA M: S-adenosylmethionine does not reduce ischemia-reperfusion injury to a marginal liver graft in an in vivo experiment. Hepatogastroenterology 59: 216-218, 2012.

PAWA S, ALI S: Liver necrosis and fulminant hepatic failure in rats: protection by oxyanionic form of tungsten. Biochim Biophys Acta 1688: 210-222, 2004.

PRAZAK J, LASZICKOVA E, PANTOFLICEK T, RYSKA O, KOBLIHOVA E, RYSKA M: Cerebral microdialysis reflects the neuroprotective effect of fractional plasma separation and adsorption in acute liver failure better and earlier than intracranial pressure: a controlled study in pigs. BMC Gastroenterol 13: 98, 2013.

RAHMAN TM, HODGSON HJF: Animal models of acute hepatic failure. Int J Exp Path 81: 145-157, 2000.

RAHMAN TM, DIAKANOV I, SELDEN C, HODGSON H: Co-transplantation of encapsulated HepG2 and rat Sertoli cells improves outcome in a thioacetamide induced rat model of acute hepatic failure. Transpl Int 18: 10011009, 2005.

RYSKA M, LASZIKOVA E, PANTOFLICEK T, RYSKA O, PRAZAK J, KOBLIHOVA E: Fractionated plasma separation and adsorption significantly decreases intracranial pressure in acute liver failure: experimental study. Eur Surg Res 42: 230-235, 2009.

RYSKA O, PANTOFLICEK T, LASZIKOVA E, PRAZAK J, KOBLIHOVA E, RYSKA M: Arterficial liver support system reduces intracranial pressure more effectively than bioarteficial system: an experimental study. Int $J$ Artl Organs 35: 503-510, 2012.

SHI Z, WAKIL AE, ROCKEY DC: Strain-specific differences in mouse hepatic would healing are mediated by divergent T helper cytokine response. Proc Natl Acad Sci USA 94: 10663-10668, 1997.

TANIGUCHI M, TAKEUCHI T, NAKATSUKA R, WATANABE T, SATO K: Molecular process in acute liver injury and regeneration induced by carbon tetrachloride. Life Sci 75: 1539-1549, 2004.

TERBLANCHE J, HICKMAN R: Animals models of fulminant hepatic failure. Dig Dis Sci 36: 770-774, 1991.

TRITTO G, DAVIES NA, JALAN R: Liver replacement therapy. Semin Respir Crit Care Med 33: 70-79, 2012. 
TUÑÓN MJ, ALVAREZ M, CULEBRAS JM, GONZÁLES-GALLEGO J: An overview of animal models for investigating the pathogenesis and therapeutical strategies in acute hepatic failure. Word J Gastroenterol 15 : 3086-3098, 2009.

YU Y, FISCHER JE, LILLEGARD JB, RODYSIL B, AMIOT B, NYBERG SL: Cell therapies for liver diseases. Liver Transpl 18: 9-21, 2012.

VANĚČKOVÁ I, KUJAL P, HUSKOVÁ Z, VAŇOURKOVÁ Z, VERNEROVÁ Z, ČERTÍKOVÁ CHÁBOVÁ V, ŠKAROUPKOVÁ P, KRAMER HJ, TESAŘ V, ČERVENKA L: Effects of combined endothelin A receptor and renin-angiotensin system blockade on the course of end-organ damage in 5/6 nephrectomized Ren-2 hypertensive rats. Kidney Blood Press Res 35: 382-392, 2012.

WEBER LW, BOLL M, STAMPFL A: Hepatotoxicity and mechanism of action of haloalkanes: carbon tetrachloride as a toxicological model. Crit Rev Toxicol 33: 105-136, 2003.

WILLIAMS CD, BAJT ML, SHARPE MR, MCGILL MR, FARHOOD A, JAESCHKE H: Neutrophil activation during acetaminophen hepatotoxicity and repair in mice and humans. Toxicol Appl Pharmacol 275: 122-133, 2014.

WLODZIMIROW KA, ESLAMI S, CHAMULEAU RAFM, NIEUWOUDT M, ABU-HANNA A: Prediction of poor outcome in patients with acute liver failure - systematic review of prediction models. PLos ONE 7: e50592, 2012.

WU Z, HAN M, CHEN T, YAN W, NING Q: Acute liver failure: mechanisms of immune-mediated liver injury. Liver Int 30: 782-794, 2010.

ZICHA J, KUNES J: Ontogenetic aspects of hypertension development: analyses in the rat. Physiol Rev 79: 1227-1282, 1999.

ZICHA J, DOBEŠOVÁ Z, VOKURKOVÁ M, RAUCHOVÁ H, HOJNÁ S, KADLECOVÁ M, BEHULIAK M, VANĚČKOVÁ I, KUNEŠ J: Age-dependent salt hypertension in Dahl rats: fifty years of research. Physiol Res 61 (Suppl 1): S35-S87, 2012. 